\title{
Dynamics of the terrestrial amphibian assemblage in a flooded riparian forest fragment in a Neotropical region in the south of Brazil
}

\author{
Maltchik, L. *, Peixoto, CD., Stenert, C., Moreira, LFB. and Machado IF. \\ Laboratório de Ecologia e Conservação de Ecossistemas Aquáticos, \\ Universidade do Vale do Rio dos Sinos - UNISINOS, \\ Av. UNISINOS, 950, CEP 93022-000, São Leopoldo, RS, Brazil \\ *e-mail:maltchik@unisinos.br
}

Received January 31, 2007 - Accepted May 10, 2007 - Distributed November 30, 2008

(With 4 figures)

\begin{abstract}
The aim of this study was to analyze the richness, abundance and composition of the terrestrial amphibian assemblage in a flooded riparian forest fragment in a Neotropical region in the south of Brazil over a year (2002-2003). A total of 1,265 terrestrial amphibians were captured, representing 12 species and six families. Leiuperidae represented 41.7 and $56.3 \%$ of the total number of species and individuals captured, respectively. The amphibian richness and abundance were higher in the Spring-Summer than in the Autumn-Winter period, and these attributes did not change after the flood events. However, the floods homogeneously distributed the amphibian species over the fragment. Our study documented the terrestrial amphibian's use in a riparian forest fragment associated to a floodplain system in the south of Brazil, showing the importance of these habitats as possible dispersal corridors among nearby wetlands.
\end{abstract}

Keywords: anuran, flood, riparian forest, wetland.

\section{Dinâmica da comunidade de anfíbios terrestres em um fragmento de floresta ripária na região Neotropical no sul do Brasil}

\begin{abstract}
Resumo
O objetivo deste estudo foi analisar a riqueza, a abundância e a composição da comunidade de anfíbios terrestres em um fragmento de floresta ripária na região Neotropical no sul do Brasil ao longo de um ano (2002-2003). Um total de 1.265 anfíbios terrestres foi capturado, representando 12 espécies e seis famílias. A família Leiuperidae representou 41,7 e 56,3\% do número total de espécies e indivíduos capturados, respectivamente. A riqueza e a abundância de anfíbios foram maiores no período primavera-verão do que no período outono-inverno, e esses atributos não variaram após as inundações. Entretanto, as inundações distribuíram homogeneamente as espécies de anfíbios ao longo do fragmento. Nosso estudo verificou o uso dos anfíbios terrestres em um fragmento de floresta ripária associada a uma planície de inundação no sul do Brasil, destacando a importância desses hábitats como possíveis corredores de dispersão entre áreas úmidas próximas.
\end{abstract}

Palavras-chave: anuro, inundação, floresta ripária, área úmida.

\section{Introduction}

Amphibians are among the most important vertebrate organisms of wetland ecosystems (Dodd and Cade, 1998). Terrestrial habitats, such as riparian forests, function as stopping points and corridors for dispersal among nearby wetlands (Brode and Bury, 1984; Semlitsch and Bodie, 2003). In the last few years, some studies have documented the use of terrestrial habitats adjacent to wetlands, by a broad range of taxa, including amphibians, which have a close dependence on these habitats for their critical life story functions (e.g., Barinaga, 1990; Borchelt, 1990; Rudolph and Dickson, 1990; McComb et al., 1993; Semlitsch, 1998).
The anuran amphibian assemblages are strongly influenced by air temperature, total amount of rainfall and hydroperiod (Wiest, 1982; Bury and Corn, 1987; Pechmann et al., 1989; Clawson et al., 1997). Temperature has an effect on many physiological processes of amphibians, including water balance, calling, metamorphosis, development and immune response (Rome et al., 1992) and rainfall is the main environmental cue that initiates reproduction for most pond-breeding anurans (Donnelly and Crump, 1998). The hydroperiod is one of the most important factors determining species richness, productivity and habitat suitability for pool or pond-breeding 
amphibians (Babbitt and Tanner, 2000; Snodgrass et al., 2000; Babbitt et al., 2003; Baber et al., 2004). Studies that analyze the effects of floods on amphibian assemblage over an annual cycle in habitats subject to disturbance by flood are scarce (Tucker et al., 1995).

The aim of this study was to analyze the richness, abundance and composition of the terrestrial amphibian assemblage in a flooded riparian forest fragment in a Neotropical region of the south of Brazil over a year (2002-2003). In this survey we analyzed the effects of air temperature, rainfall, flood occurrence and distance from the river channel on the terrestrial amphibian richness and abundance. Our approach is an exploratory analysis to infer the importance of adjacent habitats under flood disturbance in maintaining biodiversity across wetland landscape, for further hypothesis testing.

\section{Material and Methods}

\subsection{Study area}

This study was conducted in a riparian forest fragment (29 $16^{\prime} 14^{\prime \prime} \mathrm{S}$ and $49^{\circ} 50^{\prime}$ 53' W) located in a floodplain system in the lower course of the Sinos River in the State of Rio Grande do Sul (south of Brazil). The studied riparian fragment is located between the main channel of the Sinos River and a grassland system. The maximum distance between the main river channel and the grassland system is approximately $300 \mathrm{~m}$ (Figure 1). The riparian forest fragment has approximately 8 ha, and it is represented mainly by native woodland and is fed by water from precipitation, water runoff and flood events from the Sinos River. These types of habitats are very representative in the lower course of the Sinos river basin. Increase in the discharge of the Sinos River due to high precipitation originates a series of flood events that inundate all habitats of the floodplain system throughout various periods of the year. During these events, the entire forest fragment remains connected through the surface water of the Sinos River.

The Sinos River is a seventh order permanent river (Strahler, 1952) of the Jacuí/Guaíba catchment. It is $190 \mathrm{~km}$ long from its origin, at $900 \mathrm{~m}$ above sea level, as far as its confluence with the Jacuí River at an elevation of $10 \mathrm{~m}$. The annual precipitation in the Sinos River basin $\left(\sim 4,000 \mathrm{~km}^{2}\right)$ ranges from 1,200 to $2,000 \mathrm{~mm}$, and it is well-distributed throughout the year. The annual mean temperature varies between 15 and $18{ }^{\circ} \mathrm{C}$ and the minimum temperature is lower than $10^{\circ} \mathrm{C}$ in the winter, and the maximum is higher than $42{ }^{\circ} \mathrm{C}$ in the summer (Radambrasil, 1986).

\subsection{Amphibian sampling and weather data}

Twelve amphibian collections were carried out over a year (from August 2002 to July 2003) in a riparian forest fragment, distributed in two seasonal periods: six collections during the Spring-Summer period (from November 14 to March 6), and six collections during the AutumnWinter period (from March 27 to July 22). The collec-

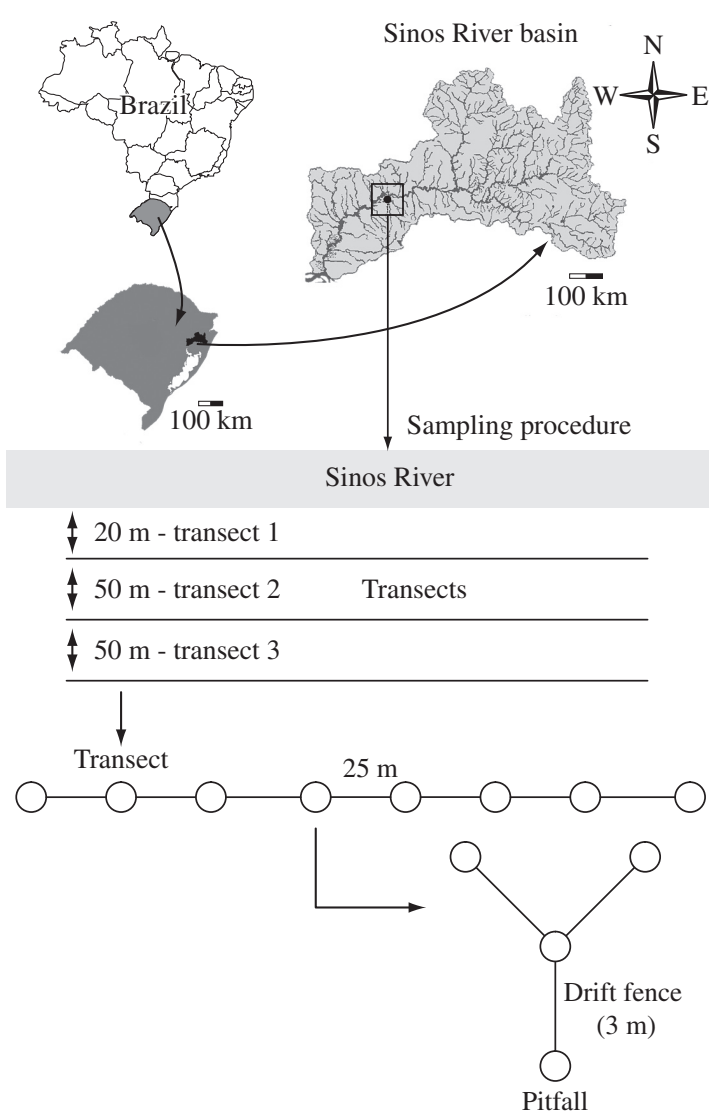

Figure 1. Position of the Sinos River basin in the south of Brazil, showing the sampling procedure.

tions performed after floods events were carried out on the first day when the studied riparian forest fragment was without surface water.

Amphibians were captured with pitfall traps, with drift fences (Corn, 1994). A total of three transects inside the riparian forest were selected: 20,70 , and 120 m away from the main channel of the Sinos River (Figure 1). A total of eight aggregate traps were prepared along each transect, $25 \mathrm{~m}$ apart from each other (Hayek and Buzas, 1997). Each aggregate trap was composed of four pitfalls (30-L plastic buckets inserted $80 \mathrm{~cm}$ deep) (Figure 1). In each collection, all pitfalls remained open for four consecutive days. Every 24 hours all amphibians collected were identified and released. The taxonomic nomenclature followed Frost (2007). The total richness and abundance observed in each pitfall throughout four days were considered as one sample, totalling 96 samples per collection.

Rainfall and mean air temperature data were measured at the Estação Meteorológica de São Leopoldo-RS. Mean air temperature corresponded to the mean of the values obtained throughout each four-day collection. Rainfall corresponded to the daily mean precipitation from the beginning of the collections (November 14). Flood duration was the amount of time (number of days) when the floodplain system remained with surface water. 
Following Tiner's classification, it was classified as very long (>one month), long (between a week and a month) and short (between two and seven days) (Tiner, 1999).

\subsection{Data analyses}

The mean richness and abundance per collection was the average number of species and individuals observed in 96 pitfalls, respectively. The variations of the mean richness and abundance of terrestrial amphibians over the year and between the three transects over the studied period were quantified through an analysis of variance (Repeated Measures ANOVA). The variations of amphibian richness and abundance, rainfall and air temperature between the two seasonal periods were quantified through a $t$-test.

A paired $t$-test was used to determine whether the significant differences in the amphibian richness and abundance existed between dates immediately prior to and after floods. If these differences were not significant ( $p>0.05)$, the terrestrial amphibian community was considered resistant to floods (Maltchik and Pedro, 2001). For the analyses, the richness values were not transformed and the abundance values and the environmental variables were log transformed to remove the heteroscedasticity.

\section{Results}

The mean precipitation was similar between the seasonal periods $(t$-test: $\mathrm{df}=250.7, \mathrm{t}=0.7, \mathrm{p}=0.478)$, and the mean air temperature was higher in the Spring-Summer (mean $\pm \mathrm{SE}=25.9 \pm 2.5^{\circ} \mathrm{C}$ ) than in the Autumn-Winter $\left(18.6 \pm 3.9{ }^{\circ} \mathrm{C}\right)(\mathrm{df}=227.5, \mathrm{t}=17.9, \mathrm{p}<0.001)$. The floodplain experienced five floods of different durations. One flood was characterized as being of very long duration (62 days), another one was characterized as being of long duration (15 days), and three were characterized as being of short duration (five to six days) (Table 1). All floods occurred after precipitation peaks (Figure 2) and all of them were enough to inundate all habitats of the floodplain system.

A total of 1,265 terrestrial amphibians, representing 12 species and six families, was collected (Table 1). Leiuperidae represented 41.7 and $56.3 \%$ of the total

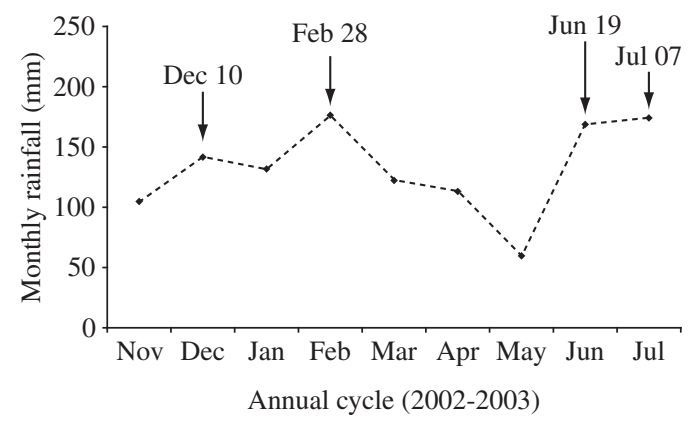

Figure 2. Monthly rainfall $(\mathrm{mm})$ over the studied period (2002-2003). Arrow = flood occurrence. number of species and individuals captured, respectively. No terrestrial amphibian species was observed in all collections. Rhinella fernandezae (Gallardo, 1957), Leptodactylus ocellatus Linnaeus, 1758, Physalaemus gracilis Boulenger, 1883, Physalaemus cuvieri Fitzinger, 1826, and Physalaemus lise $i$ Braun and Braun, 1977, were captured in more than eight collections during the studied period. Rhinella icterica (Spix, 1824), Elachistocleis bicolor Guérin-Méneville, 1838, and Pseudis minuta Günther, 1858, were observed in only one collection. L. ocellatus and P. cuvieri represented $73.2 \%$ of the total number of sampled individuals.

A total of $77.3 \%$ individuals were collected in Spring-Summer (Table 1). The Spring-Summer was characterized by the dominance of two species. While $P$. cuvieri was dominant in the beginning of this period, L. ocellatus was dominant in the end of the SpringSummer (Table 1). The Autumn-Winter started with a drastic reduction in the number of the individuals followed by an increase in the abundance of five species (L. ocellatus, Odontophrynus americanus Duméril and Bibron, 1841, P. cuvieri, P. gracilis and P. lisei) between May 22 and June 24.

The richness and abundance of terrestrial amphibians varied over the studied period (Repeated Measures ANOVA: $\mathrm{F}_{11,83}=22.476, \mathrm{p}<0.001$, and $\mathrm{F}_{11,83}=17.814$, $\mathrm{p}<0.001$, respectively) (Figure 3 and 4 ), and it was higher in the Spring-Summer (mean $\pm \mathrm{SE}=7.2 \pm 1.0$ species, and mean $\pm S E=2.1 \pm 0.1$ individuals, respectively) than in the Autumn-Winter (mean $\pm \mathrm{SE}=4.5 \pm 0.9$ species, and mean $\pm \mathrm{SE}=1.3 \pm 0.3$ individuals, respectively) $\left(\mathrm{t}_{10}=1.9, \mathrm{p}=0.045\right.$, and $\mathrm{t}_{10}=2.3, \mathrm{p}=0.044$, respectively).

The richness and abundance of terrestrial amphibians did not change after the flood events (Table 2); however, the richness of amphibians changed with the distance from the river in some collections $\left(\mathrm{F}_{22,168}=2.778\right.$, $\mathrm{p}<0.001$, and $\mathrm{F}_{22,168}=3.067, \mathrm{p}<0.001$, respectively) (Table 3). While there was some difference among

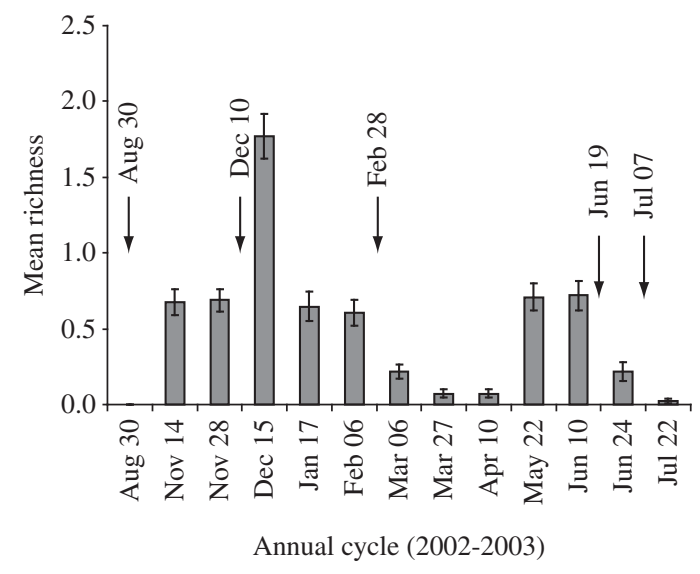

Figure 3. Richness of amphibian assemblage ( $n=96$; mean $+\mathrm{SE}$ ) in a riparian forest fragment over a year (2002-2003). Arrow $=$ flood occurrence . 


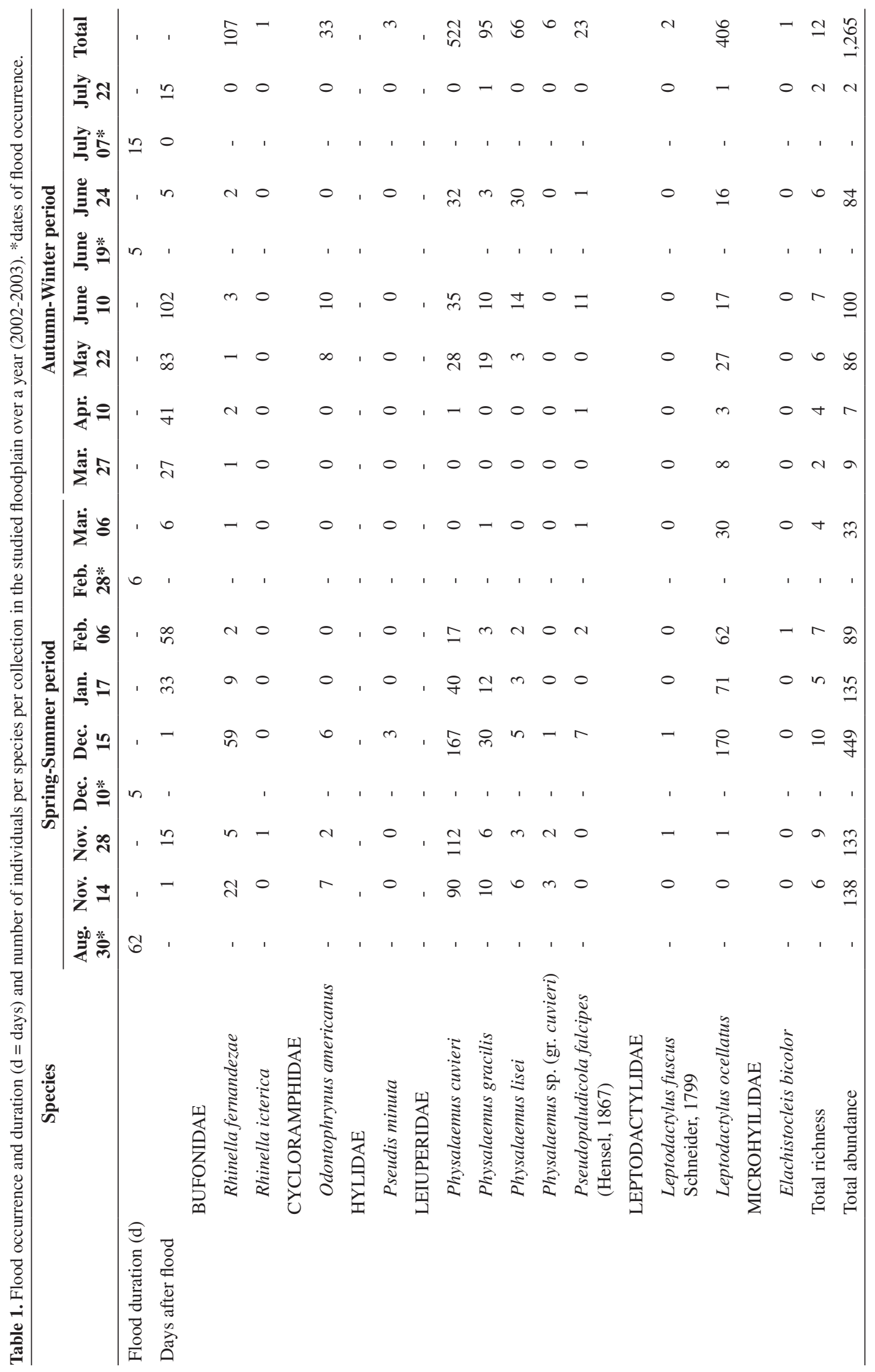




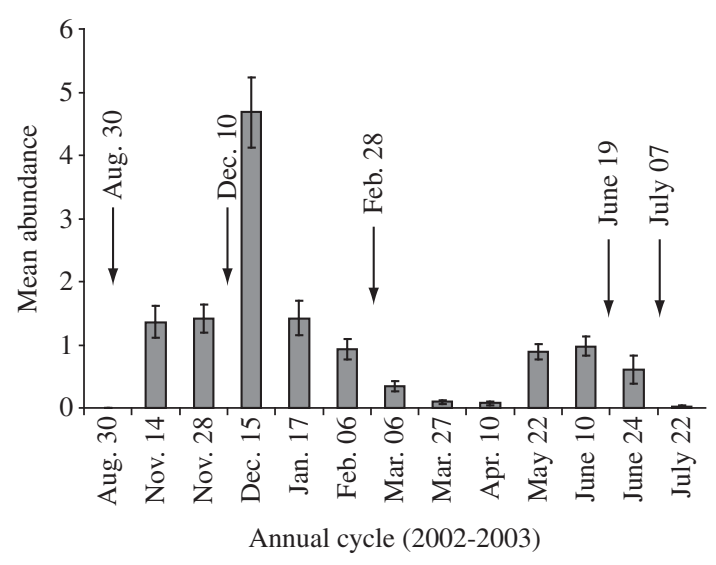

Figure 4. Abundance of amphibian assemblage ( $n=96$; mean $+\mathrm{SE}$ ) in a riparian forest fragment over a year (20022003). Arrow $=$ flood occurrence. transects in the collections before the flood events, there was no difference among them in the collections after the flood events.

\section{Discussion}

The anuran amphibian assemblages are strongly influenced by air temperature and amount of rainfall (Wiest, 1982; Bury and Corn, 1987; Clawson et al., 1997). In our study, the highest richness and abundance of terrestrial amphibians were associated with the period of highest temperature (Spring-Summer) and with the reproductive period of these observed species (Achaval and Olmos, 1997; Kwet and Di Bernardo, 1999), mainly of $L$. ocellatus that contributed a lot for the increasing of the abundance over the Spring-Summer. Rainfall also influences the reproductive period of the anuran (Duellman and Trueb, 1986), however the regular dis-

Table 2. Total richness and abundance of amphibians between collections prior to and after floods in the studied floodplain over a year (2002-2003).

\begin{tabular}{lcccc}
\hline \multicolumn{1}{c}{ Flood date } & $\begin{array}{c}\text { Richness prior to } \\
\text { floods }\end{array}$ & $\begin{array}{c}\text { Richness after } \\
\text { floods }\end{array}$ & $\begin{array}{c}\text { Abundance prior to } \\
\text { floods }\end{array}$ & $\begin{array}{c}\text { Abundance after } \\
\text { floods }\end{array}$ \\
\hline December 10 (5 days) & 10.0 & 10.0 & 134.0 & 449.0 \\
February 28 (6 days) & 7.0 & 4.0 & 89.0 & 33.0 \\
June 19 (5 days) & 7.0 & 6.0 & 100.0 & 84.0 \\
July 07 (15 days) & 6.0 & 2.0 & 84.0 & 2.0 \\
Mean & 7.5 & 5.5 & 101.7 & 142.0 \\
\hline Paired $t$-test & $\mathrm{t}_{3}=2.191, \mathrm{p}=0.116$ & $\mathrm{t}_{3}=-0.435, \mathrm{p}=0.693$ \\
\hline
\end{tabular}

Table 3. Mean richness variations between the three transects away from the river main channel in a riparian forest fragment over a year (2002-2003).

\begin{tabular}{ccccc}
\hline Collections & Transect 1 & Transect 2 & Transect 3 & Richness variations \\
\hline C1 & 0.969 & 0.594 & 0.469 & T1 > T2 and T3* \\
C2 & 0.969 & 0.625 & 0.469 & T1 > T2 and T3* \\
Second flood & - & - & - & - \\
C3 & 1.594 & 1.969 & 1.750 & NS \\
C4 & 0.719 & 0.531 & 0.688 & NS \\
C5 & 0.563 & 0.344 & 0.906 & T3 > T1 and T2* \\
Third flood & - & - & - & NS \\
C6 & 0.094 & 0.250 & 0.313 & NS \\
C7 & 0.031 & 0.156 & 0.031 & NS \\
C8 & 0.063 & 0.094 & 0.063 & T1 $>$ T2 and T3* \\
C9 & 0.969 & 0.625 & 0.531 & T2 $>$ T1 and T3* \\
C10 & 0.594 & 1.094 & 0.469 & - \\
Fourth flood & - & - & - & NS \\
C11 & 0.094 & 0.344 & 0.219 & - \\
Fifth flood & - & - & - & NS \\
\hline
\end{tabular}

$* \mathrm{p}<0.05 ;$ and NS = Not significant $(\mathrm{p}>0.05)$ 
tribution of the rainfall over the studied period did not allow the observation of this relationship. This result does not underestimate the importance of rainfall for the terrestrial amphibian's dynamic, since these events were responsible for the flood occurrence and the maintenance of the water in the floodplain system.

The flood pulses are an important factor that influences the aquatic communities in floodplain systems (Agostinho et al., 2004). Morand and Joly (1995) found that floods of short water duration influenced negatively amphibian richness. In our study, amphibian richness and abundance did not change after floods, showing a strong resistance of amphibians to disturbance by floods, including for events of different durations. However, the flood events homogeneously distributed the amphibian species over the fragment and as the flood events take longer to happen, the richness variation along the fragment returns. The homogenization effect of floods has also been observed in several assemblages of South American floodplains (Agostinho et al., 2000; Carvalho et al., 2001). Crump (1971) and Wells (1977) noticed that as anuran species have specific needs (vocalization, reproduction, shelter and foraging sites), thus making the species search different habitats which can change depending on the time of the year and the environmental conditions. The lack of floods events in the studied forest fragment allowed the amphibian species to choose their habitats with higher development possibilities.

The higher abundance of the Leiuperidae and Leptodactylidae over the studied period can be related to some biological characteristics. L. ocellatus and P. cuvieri show fast larval development - about a month - (Eterovick and Sazima, 2004) and they lay their eggs in floating foam in the vegetation, thus preventing desiccation and making the colonization of the intermitent pond easier. These reproductive strategies may have influenced the dominance of foam nests species in the area under disturbance by flood and characterized by the occurrence of shallow lakes. Drift fences with pitfall traps are commonly used to inventory terrestrial amphibians (Corn, 1994; Rocha et al., 2004). R. icterica, Leptodactylus fuscus, E. bicolor and $P$. minuta were seldom trapped probably because of regional rarity, secretive fossorial and aquatic habitats.

Our studies documented the terrestrial amphibian's use of a riparian forest fragment associated to a floodplain system in the south of Brazil, showing the importance of these habitats as possible dispersal corridors among nearby wetlands. The dominance of Leiuperidae indicated that the species of this family show strong ability to live in habitats subject to flood disturbance.

Acknowledgements - This research was supported by funds from UNISINOS (02.00.023/00-0) and CNPq (475465-01/6). L. Maltchik holds a Brazilian Research Council - CNPq Research Productivity bursary (302536/2004-3).

\section{References}

ACHAVAL, F. and OLMOS, A., 1997. Anfíbios y Reptiles del Uruguay. Montevideo: Barreiro y Ramos. 128 p.
AGOSTINHO, AA., THOMAZ, SM., MINTE-VERA, CV. and WINEMILLER, KO., 2000. Biodiversity in the High Paraná River Floodplain. In: GOPAL, B., JUNK, WJ. and DAVIS, JA. (Eds.). Biodiversity in wetlands: assessment, function and conservation. Leiden, Netherlands: Backhuys Publishers.

AGOSTINHO, AA., RODRIGUES, L., GOMES, LC., THOMAZ, SM. and MIRANDA, LE., 2004. Structure and functioning of the Paraná River and its floodplain. Maringá: EDUEM. 275 p.

BABBITT, KJ. and TANNER, GW., 2000. Use of temporary wetlands by anurans in a hydrologically modified landscape. Wetlands, vol. 20, no.2, p. 313-322.

BABBITT, KJ., BABER, MJ. and TARR, TL., 2003. Patterns of larval amphibian distribution along a wetlands hydroperiod gradient. Can. J. Zool., vol. 81, no. 9, p. 1539-1552.

BABER, MJ., FLEISHMAN, E., BABBITT, KJ. and TARR, TL., 2004. The relationship between wetland hydroperiod and nestedness patterns in assemblages of larval amphibians and predatory macroinvertebrates. Oikos, vol. 107, no. 1, p. 16-27.

BARINAGA, M., 1990. Where have all the froggies gone? Science, vol. 247, no. 4946, p. 1033- 1034.

BORCHELT, R., 1990. Scientists ponder the mysterious decline of amphibians. Atl. Nat., vol. 40, no. 1, p. 20-25.

BRODE, JM. and BURY, RB., 1984. The importance of riparian systems to amphibians and reptiles. In: WARNER, RE. and HENDRIX, KM. (Eds.). California Riparian Systems Ecology, Conservation, and Productive Management. Berkeley: University of California Press.

BURY, RB. and CORN, PS., 1987. Evaluation of pitfall trapping in northwestern forests: trap arrays with drift fences. J. Wildlife Manage., vol. 51, no. 1, p. 112-119.

CARVALHO, P., BINI, LM., THOMAZ, SM., GONÇALVES, LG., ROBERTSON, B., TAVECHIO, WLG. and DARWISCH, AJ., 2001. Comparative limnology of South American floodplain lakes and lagoons. Acta Sci., vol. 23, no. 2, p. 265-273.

CLAWSON, RG., LOCKABY, BG. and JONES, RH., 1997. Amphibian responses to helicopter harvesting in forested floodplains of low order, blackwater streams. Forest Ecol. Manag.,vol. 90, no. 3, p. 225-235.

CORN, PS., 1994. Straight-line drift fences and pitfall traps. In: HEYER, WR., DONNELY, MA., McDIARMID, RW., JAYEK, LA. and FOSTER, M. (Eds.). Measuring and monitoring biological diversity: standard methods for amphibians. Washington: Smithsonian Institution Press.

CRUMP, ML., 1971. Quantitative analysis of the ecological distribution of a tropical herpetofauna. Occ. Pap. Mus. Nat. Hist. Univ. Kansas, vol. 3, p. 1-62.

DODD, CK. and CADE, BS., 1998. Movement patterns and the conservation of amphibians breeding in small, temporary wetlands. Conserv. Biol., vol. 12, no. 2, p. 331-339.

DONNELLY, MA. and CRUMP, ML., 1998. Potential effects of climate change on two Neotropical amphibian assemblages. Clim. Change, vol. 39, no. 2-3, p. 541-561.

DUELLMAN, WE. and TRUEB, L., 1986. Biology of amphibians. New York: McGraw-Hill. 670 p.

ETEROVICK, PC. and SAZIMA, I., 2004. Anfíbios da Serra do Cipó, Minas Gerais - Brasil. Minas Gerais: PUC. 152 p. 
FROST, DR., 2007. Amphibian Species of the World: an Online Reference. Version 5.0 (15 March, 2007). New York: American Museum of Natural History. Available from: http://research. amnh.org/herpetology/amphibia/index.php.

HAYEK, LA. and BUZAS, MA., 1997. Surveying natural populations. New York: Columbia University Press. 563 p.

KWET, A. and DI-BERNARDO, M., 1999. Pró-Mata: Anfíbios. Amphibien. Amphibians. Porto Alegre: EDIPUCRS. 107 p.

MALTCHIK, L. and PEDRO, F., 2001. Responses of aquatic macrophytes to disturbance by flash floods in a Brazilian semiarid intermittent stream. Biotropica, vol. 33, no. 4, p. $566-572$.

MCCOMB, WC., MCGARIGAL, K. and ANTHONY, RG., 1993. Small mammal and amphibian abundance in streamside and upslope habitats of mature Douglas-fir stands, western Oregon. Northwest Sci., vol. 67, no. 1, p. 7-15.

MORAND, A. and JOLY, P., 1995. Habitat variability and space utilization by the amphibian communities of the French upper-Rhone floodplain. Hydrobiologia, vol. 300-301, no. 1, p. 249-257.

PECHMANN, JHK., SCOUT, DE., GIBBONS, JW. and SEMLITSCH, RD., 1989. Influence of wetland hydroperiod on diversify and abundance of metamorphosing juvenile amphibians. Wetlands Ecol. Manage., vol. 1, no. 1, p. 3-11.

RADAMBRASIL, 1986. Levantamento de Recursos Naturais. Rio de Janeiro: IBGE. 34 vol.

ROCHA, CFD., VAN SLUYS, M., HATANO, FH., BOQUIMPANI-FREITAS, L., MARRA, RV. and MARQUES, RV., 2004. Relative efficiency of anuran sampling methods in a restinga habitat (Jurubatiba, Rio de Janeiro, Brazil). Braz. J. Biol., vol. 64, no. 4, p. 879-884.
ROME, LC., STEVENS, DE. and JOHN-ALDER, H., 1992. The influence of temperature and thermal acclimation on physiological function. In: FEDER, ME. and BURGGREN, WW. (Eds.). Environmental Physiology of the Amphibians. Chicago: The University of Chicago Press.

RUDOLPH, DC. and DICKSON, JG., 1990. Streamside zone width and amphibian and reptile abundance. Southwest Nat., vol. 35 , no. 4 , p. $472-476$.

SEMLITSCH, RD., 1998. Biological delineation of terrestrial buffer zones for pond-breeding salamanders. Conserv. Biol., vol. 12, no. 5, p. 1113-1119.

SEMLITSCH, RD. and BODIE, JR., 2003. Biological criteria for buffer zones around wetlands and riparian habitats for amphibians and reptiles. Conserv. Biol., vol. 17, no. 5, p. $1219-1228$.

SNODGRASS, JW., KOMOROSKI, MJ., BRYAN Jr., AL. and BURGER, J., 2000. Relationship among isolated wetland size, hydroperiod, and amphibian species richness: implications for wetland regulations. Conserv. Biol., vol. 14, no. 2, p. 414-419.

STRAHLER, AN., 1952. Dynamics basis of geomorphology. Geol. Soc. Am. Bull., vol. 63, no. 9, p. 923-938.

TINER, RW., 1999. Wetland indicators: a guide to wetland identification, delineation, classification, and mapping. New York: Lewis Publishers. 424 p.

TUCKER, JK., SOERGEL, DW. and HATCHER, JB., 1995. Flood-associated activities of some reptiles and amphibians at Carlyle Lake, Fayette County, Illinois. Trans. Ill. State Acad. Sci., vol. 88 , no. $1 / 2$, p. $73-81$.

WELLS, KD., 1977. The social behavior of anuran amphibians. Anim. Behav., vol. 25, no. 4, p. 666-693.

WIEST, JA., 1982. Anuran succession at temporary ponds in a post oaksavanna region of Texas. In: SCOTT, NJ. (Ed.). Herpetological communities. US Fish and Wildlife Service. 